\title{
Morphological characterization of fruit, seed and seedling, and seed germination test of Campomanesia guazumifolia ${ }^{1}$
}

\author{
Michele Trombin Souza², Mireli Trombin Souza², Maristela Panobianco ${ }^{2 *}$
}

\begin{abstract}
Campomanesia guazumifolia (Cambess.) O. Berg. is a native fruit species, with ecological importance and potential to be exploited by food and medical industries. There is a lack of studies enabling its on-site conservation and propagation for commercial purposes. The objective of this work was to morphologically characterize the fruit, seed and seedling development stage of this species, as well as to determine an efficient protocol for the germination test, aiming at the commercial production of seedlings. Different temperatures $\left(20,25,30\right.$ and 20-30 ${ }^{\circ} \mathrm{C}$ ), substrates (blotting paper, sand and vermiculite) and light regimes (presence and absence) were tested in order to evaluate the germination power of seeds. Fruits are bacoid, rounded, with a fleshy pericarp and hairy surface, and with an intense yellow coloration. Seeds have a reniform shape and a lateral recess, with a membranous, brown and verrucose-glanulose tegument. It has a crass embryo, with a well developed hypocotyl-radicle axis and vestigial cotyledons. Seedlings are epigeal and phanerocotylar. It is recommended to conduct the germination test for the species with temperatures of 25 or $30{ }^{\circ} \mathrm{C}$, on paper substrates, with light presence or absence, and with the first test count performed 23 days and the final count 50 days after sowing.
\end{abstract}

Index terms: Myrtaceae, fruit tree, native species.

\section{Caracterização morfológica de frutos, sementes e plântulas, e teste de germinação de sementes de Campomanesia guazumifolia}

\begin{abstract}
RESUMO - Campomanesia guazumifolia (Cambess.) O. Berg. é uma frutífera nativa, de importância ecológica e de potencial para exploração por indústrias alimentícias e medicinais, sendo carente de estudos que viabilizem a sua conservação in situ e a propagação para fins comerciais. O trabalho teve por objetivo caracterizar morfologicamente os frutos, as sementes e o estágio de desenvolvimento de plântulas da espécie, bem como determinar um protocolo eficiente para a condução do teste de germinação, visando à produção comercial de mudas. Testaram-se diferentes temperaturas $\left(20,25,30\right.$ e $\left.20-30{ }^{\circ} \mathrm{C}\right)$, substratos (papel mataborrão, areia e vermiculita) e regimes de luz (presença e ausência) para avalição do poder germinativo das sementes. O fruto é bacóide, globoso, com pericarpo carnoso, superfície pilosa, de coloração amarelo intenso. A semente tem forma reniforme e uma reentrância lateral, com tegumento membranáceo, castanha e verrucosa-glanulosa. Possui embrião crasso, com eixo hipocótiloradícula bem desenvolvido e cotilédones vestigiais. A plântula é do tipo epígea e fanerocotiledonar. Indica-se a condução do teste de germinação para a espécie com temperaturas de 25 ou $30^{\circ} \mathrm{C}$, em substrato de papel, na presença ou ausência de luz, com a primeira contagem do teste realizada aos 23 dias e a contagem final aos 50 dias após a semeadura.
\end{abstract}

Termos para indexação: Myrtaceae, arbórea frutífera, espécie nativa.

\section{Introduction}

Campomanesia guazumifolia (Cambess.) O. Berg. is a native and uncultivated fruit plant from the Myrtaceae family, abundant in the Caatinga, Cerrado and Atlantic Forest Biomes (Lima et al., 2011). It is a perennial plant, hygrophilous, heliophile or sciophilus selective, flowering from October to December and fruiting from December to January (Sobral et al., 2015).

It presents potential economic value as an edible species, producing a remarkable quantity of fruits that are consumed by

\footnotetext{
${ }^{1}$ Submitted on 10/04/2017. Accepted for publication on 12/15/2017.

${ }^{2}$ Departamento de Fitotecnia, Universidade Federal do Paraná, Rua dos Funcionários 1540, 80035-050 - Juvevê, Curitiba, PR, Brasil.

"Corresponding author <maristela@ufpr.br>
} 
birds and bats; it is also used in the production of sweets, jams, juices and liqueurs. In traditional medicine, leaves are used in the treatment of liver diseases (Dorigoni et al., 2001). In addition, C. guazumifolia at the late secondary succession stage (slow growing species, which develops well in the shade), is considered an excellent option for mixed plantations in degraded areas and permanent preservation, in order to prepare the environment for the development of climax species (Aquino and Barbosa, 2009).

The previous knowledge of the morphology of fruits, seeds and seedlings at early stages of development is an important instrument to recognize the species inside the forest and to enable the classification of plants into groups of ecological succession. It has been reported that the particularities of seedlings are related to the environmental conditions of species occurrence and to the dispersion mechanism (Borges and Rena, 1993). Another quite useful role is the use of morphological characteristics in the analysis and interpretation of seed tests in a laboratory, providing subsidies for seed germination studies.

The multiplication of the species C. guazumifolia is given primarily by sexual way, since seeds are the most practical and economic way (Silva et al., 2017), and for this, it is necessary to have methods that evaluate their physiological quality, such as the germination test. In this regard, in order to conduct such test, favorable conditions must be provided to the germination process, such as water, substrate and temperature, as well as light availability for some species; these conditions act in isolation or interacting with each other (Marcos-Filho, 2015).

Some researches have directed their evaluations to the extrinsic factors that infer in the germination process of the Campomanesia genus. In C. xanthocarpa, germination using a paper substrate provided the highest physiological quality (germination and vigor) (Herzog et al., 2012); as for C. pubescens, for the germination test, both paper and sand were recommended (Dusseau et al., 2011). A similar behavior was observed for the species C. xanthocarpa (Santos et al., 2004) and C. pubescens (Dusseau et al., 2011), and it was verified that this condition maintains the most adequate levels of endogenous gibberellin in the species, thus favoring the synchronism of the germination process. It was also reported that temperatures between 20 and $30{ }^{\circ} \mathrm{C}$ have been indicated for the germination of species belonging to the genus Campomanesia, among which C. adamantium, $C$. guazumifolia (Dusseau et al., 2011) and C. xanthocarpa (Herzog et al., 2012); in this range, greater synchronization of the germination process occurs.

In spite of its importance, the fruits of the species are obtained from extractivism, and there is a need for studies to enable the commercial production of seedlings. In this regard, researches involving the development of methods to evaluate seed viability are relevant, as well as the knowledge of the morphological characteristics of fruits, seeds and seedlings, aiming at the identification of Campomanesia species.

The objective of this work was to characterize the fruits, seeds and seedling development stages of Campomanesia guazumifolia, as well as to determine an efficient protocol for the germination test.

\section{Material and Methods}

Ripe fruits of Campomanesia guazumifolia were collected manually from 12 matrices located in the municipality of

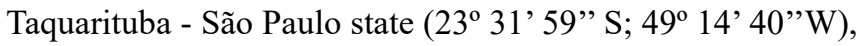
in a region of Araucaria Moist Forest, in December 2016. Seeds were extracted by depulping fruits under running water with the aid of a sieve. Initially, seed asepsis was performed with ethanol $(70 \%)$ for 30 seconds, in order to reduce surface tension, followed by disinfestation with a sodium hypochlorite solution (2\%) for 2 minutes, and then they were washed with distilled water until the complete removal of the mucilage. Seeds were then dried on paper under laboratory conditions (temperature $23 \pm 2{ }^{\circ} \mathrm{C}$ ) for 24 hours. Afterwards, they were homogenized by manual method, based on the criteria of the Rules for Seed Testing (Brasil, 2009) and divided into four replications to compose the statistical replications.

In the laboratory, the following determinations were made:

Water content: performed by oven method at $103 \pm 2{ }^{\circ} \mathrm{C}$ for 17 hours (ISTA, 2015), with two replications of $5.0 \mathrm{~g}$ of seeds; the results were expressed as percentage (wet basis).

1.000-seed weight: eight subsamples of 100 pure seeds were weighed on a precision scale with four decimal digits; the 1.000 -seed weight $(\mathrm{g})$ was obtained by multiplying the average weight obtained in the subsamples of 100 seeds by 10 , according to the methodology described by ISTA (2015).

Germination: the following temperatures were tested: $20,25,30,20-30{ }^{\circ} \mathrm{C}$; substrates: blotting paper, sand and vermiculite; without or with continuous light supply (two 40 $\mathrm{W}$ daylight-type fluorescent lamps). All substrates were preautoclaved ( $1 \mathrm{~atm}$ and $120^{\circ} \mathrm{C}, 60 \mathrm{~min}$.), except for the blotting paper, and they were placed in transparent plastic boxes (11.0 x $11.0 \times 3.5 \mathrm{~cm})$. The used sand had average granulometry (between 0.35 and $1.0 \mathrm{~mm}$ ), obtained with two soil sieves; $300 \mathrm{~g}$ of sand were added with $60 \mathrm{~mL}$ of distilled water in the plastic boxes. In the vermiculite substrate, granulometry was medium $(30 \mathrm{~g})$ and $75 \mathrm{~mL}$ of water were added in the plastic boxes. As for the blotting paper, two sheets were used in each plastic box, moistened with water in an amount equivalent 
to 2.5 times the weight of the dry substrate (ISTA, 2015). For each treatment, 50 seeds were sown, in quadruplicate, and were kept in a Mangelsdorf germinator. The results were expressed as mean percentage of normal seedlings for each treatment.

Germination rate index (GRI): conducted together with the germination test, it was evaluated by daily counts at the same time, from the observation of the first normal seedling until the 50th day, when the test ended. The results were calculated according to the formula proposed by Maguire (1962).

Fifty random samples were used for the morphological description and for the illustration of fruits and seeds, making transversal and longitudinal cuts of the material with a scalpel blade. In order to follow the development of the seedlings, five replicates of 10 seeds were sown in a vermiculite substrate, with daily observations under a stereoscopic microscope. Seedling morphology was illustrated from the protrusion of the primary root (10 days) until the development of the first pair of leaves (up to 60 days). As references to the description, the works by Landrum (1986) and Barroso et al. (1999) were consulted.

The experimental design was a completely randomized one, in a $4 \times 3 \times 2$ factorial arrangement (4 temperature levels $\mathrm{x}$ 3 substrate levels x 2 light levels), with four replications. Data were submitted to analysis of variance by F test $(p<0.01)$, and means were compared by the Scott-Knott test ( $\mathrm{p} \leq 0.01)$. For the results of the morphological characterization, descriptive analyses of the data were carried out.

\section{Results and Discussion}

The fruit of Campomanesia guazumifolia is called baccate (berry), with a rounded shape, indehiscent, polyspermic, with a fleshy consistency and a hairy surface; it has a marcescent chalice that remains throughout the development of the fruit, with an intense yellow color after ripening (Figure 1A). It has 6 to 10 seeds per fruit, with an average of 5.5 $\mathrm{mm}$ in length and $4.8 \mathrm{~mm}$ in diameter (Table 1). It is worth mentioning that the fruits from the Campomanesia species are campomanesian-type berries (Brasil, 2009); this is one of the characteristics for the taxonomic classification of this genus. They are constituted by narrow locules containing few seeds, with a central cavity filled with a fleshy and transparent pulp (Barroso et al., 1999).

As for the seeds, they are considered exalbuminous; they are reniform, with a rounded base and apex, and a lateral recess (Figure 1E). They are, on an average, $4.0 \mathrm{~mm}$ long, $3.3 \mathrm{~mm}$ wide and $2.2 \mathrm{~mm}$ thick (Table 1). The tegument is

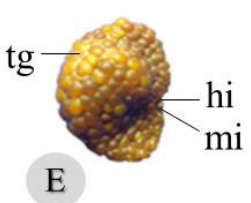

E

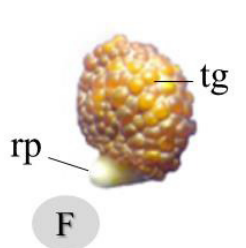

F

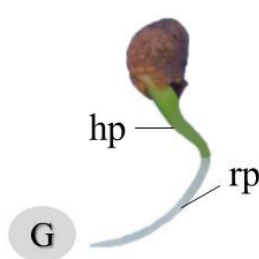

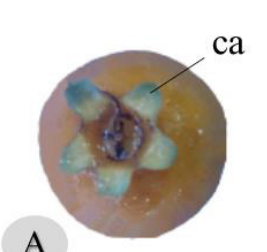

A

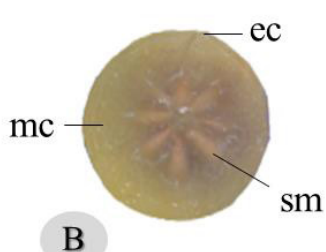

$\mathrm{p}$

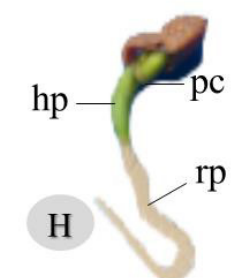

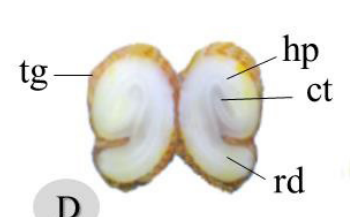

D

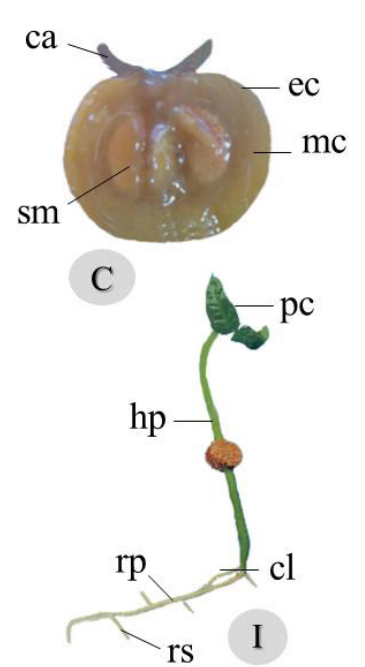

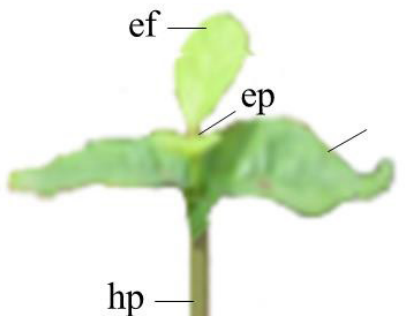

hp

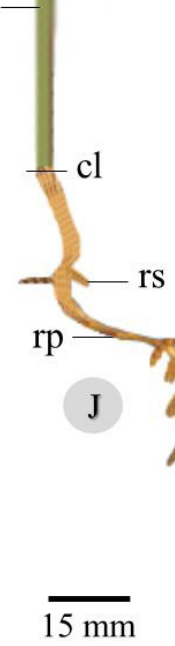

Figure 1. Morphology of Campomanesia guazumifolia fruit, seed and seedling. A- External aspect of the fruit; B- cross section of the fruit; C- longitudinal cut of the fruit; D- embryo; E-seeds; F to J- development stage of the seedling; ca - chalice; sm - seeds; mc - mesocarp; ec - epicarp; tg - tegument; ct - cotyledon; hp-hypocotyl; rd - radicle; hi - hilum; mi - micropyle; rp - primary root; rs - secondary root; pc - paracotyledon; cl - stem; ep - epicotyl; ef - first leaves. $\mathrm{n}=50$. 
Table 1. Biometric characterization of fruits and seeds of (Campomanesia guazumifolia).

\begin{tabular}{|c|c|c|c|c|c|}
\hline \multirow{2}{*}{ EVALUATIONS } & \multicolumn{4}{|c|}{ VARIATIONS } & \multirow[b]{2}{*}{ Var. Coef.(\%) } \\
\hline & Minimum & Medium & Maximum & Standard Deviation & \\
\hline \multicolumn{6}{|l|}{ FRUIT } \\
\hline - Length (mm) & 5.0 & 5.5 & 6.4 & 0.57 & 10.36 \\
\hline -Diameter (mm) & 4.0 & 4.8 & 5.1 & 0.47 & 9.79 \\
\hline \multicolumn{6}{|l|}{ SEED } \\
\hline - Length (mm) & 3.0 & 4.0 & 5.0 & 0.43 & 10.75 \\
\hline - Width (mm) & 3.0 & 3.3 & 4.0 & 0.46 & 13.94 \\
\hline - Thickness (mm) & 2.0 & 2.2 & 3.0 & 0.01 & 0.45 \\
\hline -N. of seeds/fruit & 6 & 7 & 10 & 0.83 & 11.86 \\
\hline
\end{tabular}

Var. Coef. $(\%)=$ Variation coefficient $(\%), n=50$

membranous, verrucose-glandulose (Landrum, 1986) and has a evenly distributed brown color (Figure 1E). It is worth mentioning the verrucose-glandulose aspect of seeds, which has been used as an important taxonomic characteristic to define the genus for Myrtaceae.

The crass-type embryo is wound in a spiral; the hypocotylradicle axis develops greatly, with vestigial cotyledons located at the apex (Figure 1D). This type of embryo is the specialized form of the pimentoid embryo (Barroso et al., 1999).

The growth of $C$. guazumifolia is characterized by five development stages of the seedling (Figure 1). Seedling development begins on the 10th day after sowing, culminating with an opening in the micropyle region and the protrusion of the primary root. The root is short, thick, glabrous, white and with a pointed apex (Figure 1F). From the 15th day, the primary root lengthens and creates a downward curve, and the hypocotyl with a curved aspect also expands towards the surface of the substrate (Figure 1G), raising the paracotyledons that are still attached to the tegument, probably exerting a haustorial function, until the reserves of the cotyledons are consumed (Figure 1H). At the 20th day, the paracotyledons are exposed and reduced (Figure 1H). With the expansion of the paracotyledons, the hypocotyl becomes wound in a spiral, with a dark green color (Figure 1). The stem can be visualized by the distinct demarcation at the base of the hypocotyl (Figure 1I). On the 60th day, the development of the first pair of leaves, with opposite phyllotaxis, smooth margins and penninerve veins (Figure 1J).

The collected lot of C. guazumifolia had a 1.000-seed weight of $65.4 \mathrm{~g}$ and a seed number of 14.058 per kilogram. This information provides subsidies for the estimate of the seed size, as well as its maturity and density (Brasil, 2009). The seed weight is related to the maturation process, being associated with the seed development and the number and size of the cells in the embryo, endosperm and tegument (Ohto et al., 2009); it is strongly influenced by the genetic diversity of the species, especially of the maternal progenitors (Li et al., 2011).
Data on water content revealed that the seeds had a content of $38.7 \%$ at the beginning of the experiments. According to the recommendations from the Rules for Seed Testing (Brasil, 2009), the water content is directly linked to the 1.000 -seed weight, and may vary according to the conditions of the collection site, the age, and the maturity of seeds (Marcos-Filho, 2015). In this regard, the water content value (38.7\%) found for the species in this study shows the significant variation of this characteristic according to the environment and maturation stage, since Santos et al. (2004), when working with immature seeds from the same species, collected in Boa Vista do Cadeado (Rio Grande do Sul state), obtained a $9.0 \%$ water content.

For the germination of C. guazumifolia seeds, the temperature $\mathrm{x}$ substrate $\mathrm{x}$ light regime factors were not independent (Table 2). It was found that temperatures of 25 and $30{ }^{\circ} \mathrm{C}$ provided higher percentages of germination on all tested substrates, both with the presence and absence of light (Table 2). As for the substrates, paper stands out; it provided greater performance at both best temperatures, regardless of the tested light regime; however, at $25^{\circ} \mathrm{C}$ there was no difference between the studied substrates and light regime. The paper substrate is one of the most suitable to conduct a laboratory germination test (Brasil, 2009), since it is already present in the analysis routine of several species, with practical handling. This result resembles those mentioned in literature, such as the ones by Herzog et al. (2012), who observed that the paper substrate helped the germination of C. xanthocarpa, compared to the sand substrate; and those by Dusseau et al. (2011), who recommended the paper or sand substrate for the germination of $C$. pubescens, however observing that the paper substrate helped visualizing the root protrusion.

The possibility of installing the test without the provision of artificial light, according to the obtained results, allows carrying out the analysis with a more basic and cheaper equipment. It is worth highlighting, however, that the provision of artificial light during the test, when possible, 
Table 2. Germination (\%) of Campomanesia guazumifolia seeds at different temperatures, substrates and light regimes.

\begin{tabular}{|c|c|c|c|c|c|c|}
\hline \multicolumn{7}{|c|}{ Germination $(\%)$} \\
\hline \multirow{3}{*}{ Temperature $\left({ }^{\circ} \mathrm{C}\right)$} & \multicolumn{6}{|c|}{ Substrate } \\
\hline & \multicolumn{2}{|c|}{ Paper } & \multicolumn{2}{|c|}{ Sand } & \multicolumn{2}{|c|}{ Vermiculite } \\
\hline & Presence of light & Absence of light & Presence of light & Absence of light & Presence of light & Absence of light \\
\hline 20 & $56 \pm 3.74 \mathrm{bA}^{*}$ & $56 \pm 8.08 \mathrm{bA}$ & $38 \pm 3.65 \mathrm{bB}$ & $37 \pm 5.88 \mathrm{bB}$ & $39 \pm 3.74 \mathrm{bB}$ & $37 \pm 4.94 \mathrm{bB}$ \\
\hline 25 & $83 \pm 2.94 \mathrm{aA}$ & $84 \pm 6.70 \mathrm{aA}$ & $79 \pm 3.74 \mathrm{aA}$ & $81 \pm 5.05 \mathrm{aA}$ & $78 \pm 7.17 \mathrm{aA}$ & $80 \pm 12.13 \mathrm{aA}$ \\
\hline 30 & $88 \pm 8.47 \mathrm{aA}$ & $87 \pm 6.78 \mathrm{aA}$ & $81 \pm 5.26 \mathrm{aB}$ & $81 \pm 5.06 \mathrm{aB}$ & $80 \pm 8.08 \mathrm{aB}$ & $79 \pm 8.68 \mathrm{aB}$ \\
\hline $20-30$ & $51 \pm 3.74 \mathrm{bA}$ & $53 \pm 3.41 \mathrm{bA}$ & $30 \pm 6.68 \mathrm{cC}$ & $31 \pm 3.74 \mathrm{cC}$ & $25 \pm 2.25 \mathrm{cC}$ & $39 \pm 5.06 \mathrm{bB}$ \\
\hline
\end{tabular}

*Averages followed by the same letter, lowercase in the column and upper case on the line, do not differ from each other at $5 \%$, by the Scott-Knott test. \pm standard deviation, $\mathrm{n}=4$.

is recommended to help the development of the essential structures of seedlings, facilitating the evaluation and reducing the attack of microorganisms (Brasil, 2013).

It is known that the induction of germination occurs within certain temperature limits, which are the result of physiological adaptations of the seeds to the places of occurrence and the stages of ecological succession (Figliolia and Silva, 2015). It has also been reported that temperatures of $25^{\circ} \mathrm{C}$ and $30^{\circ} \mathrm{C}$ are the most favorable for the germination of seeds from tree species (Brancalion et al., 2010); thus, it is expected that $C$. guazumifolia seed present the plasticity of germinating at such temperatures. In addition, germination occurs within temperature limits, since for seeds from each species there are cardinal temperatures for germination, that is, maximum, minimum and optimal temperatures for the process to occur (Marcos-Filho, 2015).

The germination rate of $C$. guazumifolia seeds evaluated by the GRI was also higher at temperatures of 25 and $30{ }^{\circ} \mathrm{C}$, both with the presence and absence of light, in all studied substrates (Table 3). Sand and paper had greater performance than vermiculite at such temperatures.

Although the sand substrate may be indicated to conduct the test on C. guazumifolia seeds, it is worth highlighting that it is not routinely used in laboratories, because it presents greater difficulties for the installation of the germination test
(Marcos-Filho et al., 1987). It must be sterilized and sieved beforehand, causes problems in maintaining the laboratory clean, and it makes it difficult to examine the roots. In addition, although this substrate is recommended by the Rules for Seed Testing (Brasil, 2009), there are serious problems in its use regarding the distribution of particle size and water retention capacity, which may cause excessive water drainage and surface dryness (Periotto and Gualtieri, 2017). According to Marcos-Filho et al. (1987), there are other difficulties in working with the sand substrate, such as the standardization of the volumetric weight, the $\mathrm{pH}$ and the electrical conductivity.

It is therefore possible to state that the best conditions to conduct a germination test (combining higher percentage and rate) were 25 or $30^{\circ} \mathrm{C}$ in the paper substrate, and there was no need to use artificial light for the species. Similar results were found for the species C. xanthocarpa (Santos et al., 2004) and C. pubescens (Dusseau et al., 2011), which presented an indifferent behavior to light; according to Dusseau et al. (2011), this behavior maintains the most adequate levels of endogenous gibberellin in the species, thus helping the synchronism of the germination process.

Figure 2 shows the number of normal seedlings obtained at each evaluation day of the germination test, conducted at 25 and $30^{\circ} \mathrm{C}$, in the paper and sand substrates, with the presence and absence of light. It is possible to observe that

Table 3. Germination Rate Index (GRI) of Campomanesia guazumifolia seeds, at different temperatures, substrates and light regimes.

\begin{tabular}{|c|c|c|c|c|c|c|}
\hline \multicolumn{7}{|c|}{ Germination rate index } \\
\hline \multirow{3}{*}{ Temperature $\left({ }^{\circ} \mathrm{C}\right)$} & \multicolumn{6}{|c|}{$\begin{array}{ll}\text { Substrate } \\
\end{array}$} \\
\hline & \multicolumn{2}{|c|}{ Paper } & \multicolumn{2}{|c|}{ Sand } & \multicolumn{2}{|c|}{ Vermiculite } \\
\hline & Presence of light & Absence of light & Presence of light & Absence of light & Presence of light & Absence of light \\
\hline 20 & $1.5 \pm 0.05 \mathrm{cA}^{*}$ & $1.3 \pm 0.10 \mathrm{bA}$ & $1.0 \pm 0.11 \mathrm{cB}$ & $0.8 \pm 0.06 \mathrm{bB}$ & $0.9 \pm 0.04 \mathrm{bB}$ & $0.9 \pm 0.06 \mathrm{bB}$ \\
\hline 25 & $3.3 \pm 0.14 \mathrm{aA}$ & $3.5 \pm 0.14 \mathrm{aA}$ & $3.2 \pm 0.08 \mathrm{aA}$ & $3.2 \pm 0.11 \mathrm{aA}$ & $2.8 \pm 0.13 \mathrm{aB}$ & $2.8 \pm 0.20 \mathrm{aB}$ \\
\hline 30 & $3.5 \pm 0.14 \mathrm{aA}$ & $3.5 \pm 0.14 \mathrm{aA}$ & $3.4 \pm 0.15 \mathrm{aA}$ & $3.5 \pm 0.11 \mathrm{aA}$ & $2.8 \pm 0.11 \mathrm{aB}$ & $2.7 \pm 0.15 \mathrm{aB}$ \\
\hline $20-30$ & $1.8 \pm 0.74 \mathrm{bA}$ & $1.7 \pm 0.12 \mathrm{bA}$ & $1.4 \pm 0.13 \mathrm{bB}$ & $1.0 \pm 0.11 \mathrm{bC}$ & $1.1 \pm 0.05 \mathrm{bC}$ & $1.1 \pm 0.09 \mathrm{bC}$ \\
\hline
\end{tabular}

*Averages followed by the same letter, lowercase in the column and upper case in the row, do not differ from each other at $5 \%$, by the Scott-Knott test. \pm standard deviation, $\mathrm{n}=4$. 


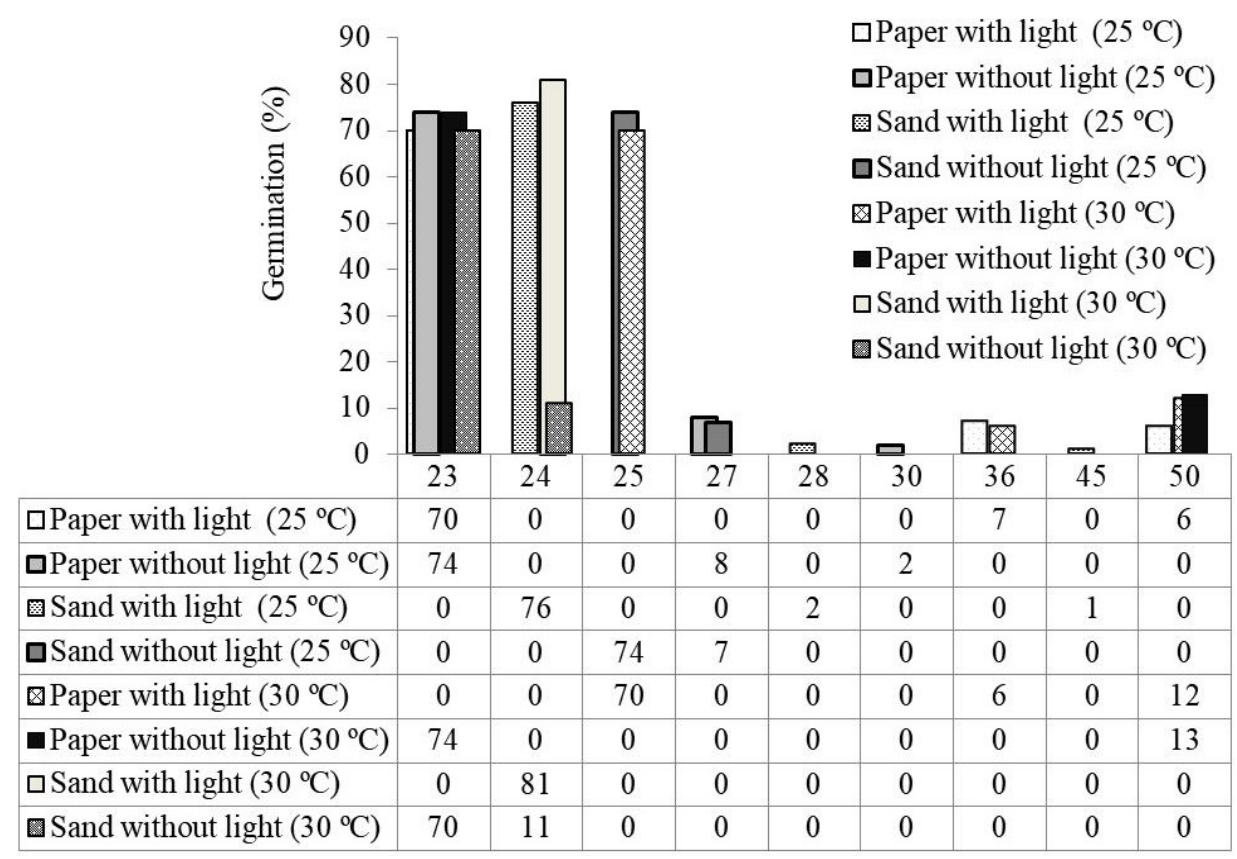

Figure 2. Percentage of Campomanesia guazumifolia normal seedlings according to the number of days after sowing, obtained at temperatures of $25^{\circ} \mathrm{C}$ and $30^{\circ} \mathrm{C}$, in paper and sand substrates, with the presence and absence of light. $\mathrm{n}=4$.

the first count of the test may be performed at the 25th day for all treatments; test closing is indicated 50 days after sowing, highlighting that the first count was defined when there was the highest production of normal seedlings, and the last count of the test was defined when formation of seedlings stabilized.

Intact seedlings of $C$. guazumifolia were considered normal whn they had an approximate size of $3 \mathrm{~cm}$, and when the primary root was developed and covered by numerous absorbing hairs, with a curved hypocotyl and two green paracotyledons in opposite position. This normal intact seedling criterion is in accordance with the requirements established in the Rules for Seed Testing (Brasil, 2009).

Thus, the normal seedling criterion and the definition of dates for the germination test evaluation are fundamental to determine an efficient protocol to conduct the test on $C$. guazumifolia.

\section{Conclusions}

Campomanesia guazumifolia fruits are berrytype, rounded, with a fleshy pericarp, hairy surface and intense yellow color. Seeds are exalbuminous, reniform, with a rounded base and apex, and a lateral recess, with a membranous, brown and verrucose-glandulose tegument. The embryo is crass, with a well developed hypocotyl-radicle axis and vestigial cotyledons located at the apex. The seedling is epigeous and phanerocotylar.
The seed germination test of Campomanesia guazumifolia can be conducted on a paper substrate, at a temperature of 25 or $30^{\circ} \mathrm{C}$, with the presence or absence of light; the first count occurs 25 days and the final count 50 days after sowing.

\section{Acknowledgment}

To the Coordenação de Aperfeiçoamento de Pessoal de Nível Superior (CAPES) and the Conselho Nacional de Desenvolvimento Científico e Tecnológico (CNPq) for the granted scholarships.

\section{References}

AQUINO, C.; BARBOSA, L.M. Classes sucessionais e síndromes de dispersão de espécies arbóreas e arbustivas existentes em vegetação ciliar remanescente (Conchal, SP), como subsídio para avaliar o potencial do fragmento como fonte de propágulos para enriquecimento de áreas revegetadas no rio Mogi-Guaçu, SP. Revista Árvore, v.33, n.2, p.349-358, 2009. http://www.scielo.br/scielo. php?script $=$ sci_arttext\&pid=S0100-67622009000200016

BARROSO, G.M.; MORIM, M.P.; PEIXOTO, A.L.; ICHASO, C.L.F. Frutos e sementes: morfologia aplicada à sistemática de dicotiledôneas. Viçosa: UFV, 1999. 443p.

BRASIL. Ministério daAgricultura, Pecuária eAbastecimento. Regras para análise de sementes. Ministério da Agricultura, Pecuária e Abastecimento. Secretaria de Defesa Agropecuária. Brasília: MAPA/ACS, 2009. 395p. http://www.agricultura.gov.br/arq editor/ file/2946_regras_analise_sementes.pdf 
BRASIL. Ministério da Agricultura, Pecuária e Abastecimento. Glossário Ilustrado da Morfologia. Ministério da Agricultura, Pecuária e Abastecimento. Secretaria de Defesa Agropecuária. Brasília: MAPA/ACS, 2009. 410p. http://www.agricultura.gov.br/ assuntos/laboratorios/arquivos-publicacoes-laboratorio/glossario ilustrado_morfologia-23.pdf

BRASIL. Ministério da Agricultura, Pecuária e Abastecimento. Instruções para análise de sementes de espécies florestais. Ministério da Agricultura, Pecuária e Abastecimento. Secretaria de Defesa Agropecuária. Brasília: MAPA/SDA, 2013. 97p. http://www. agricultura.gov.br/assuntos/laboratorios/arquivos-publicacoeslaboratorio/florestal_documento_pdf-ilovepdf-compressed.pdf

BORGES, E.E.L.; RENA, A.B. Germinação de sementes. In: AGUIAR, I.B.; PIÑA-RODRIGUES, F.C.M.; FIGLIOLIA, M.B. (Ed.). Sementes florestais tropicais. Brasília: ABRATES, 1993. p.83-136.

BRANCALION, P.H.S.; NOVEMBRE, A.D.L.C.; RODRIGUES, R.R. Temperatura ótima de germinação de espécies arbóreas brasileiras. Revista Brasileira de Sementes, v.32, n.4, p.15-21, 2010. http://www. scielo.br/scielo.php?pid=S0101-31222010000400002\&script $=$ sci_ abstract\&tlng=pt

DORIGONI, P.A.; GHEDINI, P.C.; FRÓES, L.F.; BAPTISTA, K.C.; ETHUR, A.B.M.; BALDISSEROTTO, B.; BÜRGER, M.E.; ALMEIDA, C.E.; LOPES, A.M.; ZÁCHIA, R.A. Levantamento de dados sobre plantas medicinais de uso popular no município de São João do Polêsine, RS, Brasil. I - Relação entre enfermidades e espécies utilizadas. Revista Brasileira de Plantas Medicinais, v.4, n.1, p.69-79, 2001. http://www.ibb.unesp.br/Home/Departamentos/ Botanica/RBPM-RevistaBrasileiradePlantasMedicinais/artigo_9_ v4_\%20n1.pdf

DUSSEAU, S.; ALVARENGA, A.A.; GUIMARÃES, R.M.; LARA, T.S.; CUSTÓDIO, T.N; CHAVES, I.S. Ecophysiology of Campomanesia pubescens seed germination. Ciência Rural, v.41, n.8, p.1362-1368, 2011. http://www.scielo.br/pdf/cr/v41n8/ a8811cr4425.pdf

FIGLIOLIA, M.B.; SILVA, A. Sementes florestais tropicais: da ecologia à produção. 2ed. Londrina: ABRATES, 2015. p.289-307.

HERZOG, F.M.; MALAVASI, M.M.; MALAVASI, U.B.C. Fruit morfometry and germination of Campomanesia xanthocarpa $\mathrm{O}$. BERG seeds. Semina, v.33, n.4, p. 1359-1366, 2012. http://www.uel. $\mathrm{br} / \mathrm{revistas} / \mathrm{uel} /$ index.php/semagrarias/article/view/7429/11235

ISTA. International Rules for Seed Testing. 2015 ed. Bassersdorf: ISTA, 2015. 276p.

LANDRUM, L.R. Campomanesia, Pimenta, Blepharocalyx, Legrandia, Acca, Myrrhinium and Luma (Myrtaceae). Flora Neotropica, v.45, p.116-160, 1986. https://www.jstor.org/stable/4393795?seq=1\#page_ scan_tab_contents
LI, Z.; LU, W.; YANG, L.; KONG, X.; DENG, X. Seed weight and germination behavior of the submerged plant Potamogeton pectinatus in the arid zone of northwest China. Ecology and Evolution, v.5, n.7, p.1504-1512, 2011. https://www.ncbi.nlm.nih. gov/pmc/articles/PMC4395179/pdf/ece30005-1504.pdf

LIMA, D.F.; GOLDENBERG, R.; SOBRAL, M. O gênero Campomanesia (Myrtaceae) no estado do Paraná, Brasil. Rodriguésia, v.62, p.683-693, 2011. http://rodriguesia-seer.jbrj.gov. br/index.php/rodriguesia/article/view/119/112

MAGUIRE, J.D. Speed of germination aid in selection and evaluation for seedling and vigour. Crop Science, v.2, p.176-177, 1962.

MARCOS-FILHO, J. Fisiologia de sementes de plantas cultivadas. 2ed. Londrina: ABRATES, 2015. 660p.

MARCOS-FILHO, J.; CICERO, S.M.; SILVA, W.R. Avaliação da qualidade das sementes. 1ed. Piracicaba: FEALQ, 1987. 230p.

OHTO, M.; FLOYD, S.K.; FISCHER, R.L.; GOLDEBERG, R.B.; HARADA, J.J. Effects of APETALA2 on embryo, endosperm, and seed coat development determine seed size in Arabidopsis. Sexual Plant Reproduction, v. 22, n.4 p. 277-289, 2009. https://www.ncbi. nlm.nih.gov/pmc/articles/PMC2796121/

PERIOTTO, F.; GUALTIERI, S.C.J. Seed germination and inicial development of Campomanesia pubescens (DC.) O. Berg (Myrtaceae) in different substrates. Ciência Florestal, v.27, n.3, p. 743-752, 2017. http://www.scielo.br/pdf/cflo/v27n3/1980-5098-cflo-27-03-00743.pdf

SANTOS, C.M.R.; FERREIRA, A.G.; ÁQUILA, M.E.A. Fruits characteristics and germination of seeds of six natives Myrtaceae species from Rio Grande do Sul. Ciencia Florestal, Santa Maria, v.14, n.2, p. 13-20, 2004. http://coral.ufsm.br/cienciaflorestal/ artigos/v14n2/A2V14N2.pdf

SILVA, O.G.; LOPES, K.P.; CAVALCANTE, J.A.; PEREIRA, N.A.E.; BARBOSA, R.C.A. Pre-germinative treatments in pomegranate seeds (Punica granatum L.): effect on physiological quality. Revista Brasileira de Fruticultura, v.39, n.spe. p.1-5, 2017. http://www.scielo. $\mathrm{br} / \mathrm{pdf} / \mathrm{rbf} / \mathrm{v} 39$ nspe/0100-2945-rbf-39-Spe-e-732.pdf

SOBRAL, M.; PROENÇA, C.; SOUZA, M.; MAZINE, F.; LUCAS, E. 2015. Myrtaceae. In: Forzza, R.C. (org.). Lista de espécies da flora do Brasil. Disponível em http://floradobrasil.jbrj.gov.br/jabot/ floradobrasil/FB10307. Acess on: 29 sep. 17. 